Arab Univ. J. Agric. Sci., Ain Shams Univ., Cairo, 14(2), 625-639, 2006

\title{
GROWTH, YIELD AND YIELD COMPONENT OF INOCU- LATED CHICKPEA AND FABA BEAN PLANTS AS AFFECTED BY USING METHYLOTROPHIC BACTERIA \\ [40]
}

\author{
Shehata, Sawsan F. ${ }^{1}$; H.H. Abo Taleb ${ }^{2}$; Wedad E.E. Eweda ${ }^{1}$ \\ and Heba O.M. Orf ${ }^{2}$
}

\begin{abstract}
Two pot experiments were performed in Giza research station, Agricultural Research Center (ARC) using 2 isolates of Pink-Pigmented Facultatively Methylotrophic bacteria (PPFMs) originated from chickpea and Faba bean. Foliar application with PPFM isolates were conjugated with specific rhizobial inoculum and Nfertilization $\left(15 \mathrm{Kg} \mathrm{N} \mathrm{Fed}^{-1}\right)$. Nodulation status, nitrogen fixation and growth yield and yield component were recorded. Results clearly indicated that Chickpea was superior in its response to foliar application with PPFM.C. As it gave higher records of number and dry weight of nodules, dry matter and $\mathrm{N}$-content of plants as compared to Faba bean. A field experiment was also conducted in sandy loam soil at South EL-Tahreer province to investigate the effect of foliar application with PPFM.C strain + specific Rhizobia and N-fertilization on nodulation, growth and yield of chickpea legume plants. Results indicated that foliar application with PPFM.C in the presence of specific rhizobial inoculation scored significant increases in economic turnover of chickpea in the range of $21-32 \%$ as compared to $\mathrm{N}$-fertilization at rate $50 \mathrm{Kg} \mathrm{N} \mathrm{Fed}^{-1}$. Foliar application with $5 \mathrm{~L} \mathrm{Fed}^{-1}$ in the presence of $15 \mathrm{Kg} \mathrm{N} \mathrm{Fed}^{-1}$ and specific rhizobial inoculation led to an increase of $518 \mathrm{~kg} \mathrm{fed}^{-1}$ productivity of seed yield, with economic turnover of 2491 L.E.
\end{abstract}

Keywords: Rhizobium leguminosarum, Nitrogen Fixation, Pink-Pigmented, Facultatively Methylotrophic bacteria (PPFMs), Foliar Application, Economic turnover, Faba bean, Chickpea.

\section{INTRODUCTION}

The extensive use of chemicals for increasing of agricultural production led to increase both production cost and environmental pollution leading to many health hazards. To avoid some of these problems, a wide variety of Plant Growth

1 Department of Agricultural Microbiology, Faculty of Agriculture, Ain Shams University, Shoubra El-Kheima, Cairo, Egypt

2- Department of Agricultural Microbiology, Soils, Water and Environment Research Institute, Agricultural Research Center, Giza, Egypt 
Promoting Rhizobacteria (PGPR) which stimulate of growth of their host by one or more of different mechanisms, these bacteria are called were extensively used (Frankenberger \& Arshad, 1995).

The search for PGPR and investigation of their modes of action are increasing to exploit them commercially as biofertilizers fixing nitrogen, increasing the availability of nutrients in the rhizosphere, positively influencing both morphology and growth of roots and promoting other beneficial plant-microbe symbiosis.

One of the most traditionally exploited rhizobacteria are root nodule bacteria is nitrogen fixation in legumes; it depends upon a highly coordinated sequence of interactions between plants of the family leguminosae and the genera of rhizobia group, which results in the formation of root nodules in a symbiotic association system (Arshad and Frankenberger, 1998).

Many microbes live on phylloplane and feed on materials leached from the leaf. Phylloplane bacteria produce Bvitamins, auxins and cytokinins among other products. The term methylotrophic is used to describe a wide variety of bacteria, which can utilize single carbon compounds more reduced than carbon dioxide as sole carbon source (Lidstorm 2002).

The most abundant group of methylotrophs isolated from surfaces of green plants were Pink Pigmented Facultatively Methylotrophs (PPFMs) (Holland, 1997a).

The present work is conducted to study the relationship between methylotrophic bacteria (PPFMs) and inoculated legume plants with rhizobia under greenhouse and field conditions.

\section{MATERIAL AND METHODS}

\section{Soil used}

The soil used in greenhouse experiments were collected from El-Tahady sector, South El-Tahreer Province, Behera Governorate. The field experiment was conducted in the same site. Mechanical and chemical analysis of the soil sample in both experiments was carried out according to Jackson (1973) at soil analysis Lab., Soils, Water and Environment Research Institute, ARC, Giza, and was shown in Table (1).

\section{Seeds used}

Seeds of Faba bean (Vicia faba) variety Nubaria 1 and chickpea (Cicer arietinum) variety Giza 195 were used in greenhouse and field experiments. They were kindly supplied with Field Crop Research Institute, Agricultural Research Center (ARC), Giza, Egypt.

\section{Bacterial strains and isolates used}

Four strains of Rhizobium leguminosarum bv. viciae namely ICARDA 31 and NIFTAL 1148 specific to chickpea and ICARDA 441 and ARC 207 specific to Faba bean were obtained from biofertilizers production unit, Agricultural Microbiology Dept., Soils, Water and Environment Research Institute, ARC, Giza, Egypt, and two PPFM strains (PPFM.C \& PPFM.F) which were isolated and identified by Orf, et al (2005) . 


\section{Greenhouse experiments}

Seeds of chickpea (Giza 195) and faba bean (Nubaria 1) were planted in sterilized pots of $30 \mathrm{~cm}$ diameter each filled with $10 \mathrm{~kg}$ washed and sterilized sandy loam soil, seedlings were thinned after two weeks to three seedlings per pot.

The seeds of chickpea and faba bean were inoculated twice, at planting and after two weeks with $10 \mathrm{~mL}$ of liquid mixture of rhizobial strains(containing $3 \times 10^{9}$ cells $\mathrm{mL}^{-1}$ ) specific to both legumineous plants, which were enrichment with YEM broth medium (Vincent, 1970) .

The inoculation with the PPFMs bacteria was carried out by applying both soaking and foliar methods, which were sub cultured on Met-AMS broth medium according to Holland and Polacco (1994) .

The layout of the experiments (Fig. 1) consisted of 16 treatments with 3 replicates in a complete randomized block design.

The recommended doses of NPK fertilizers were used as follows: super phosphate $\left(15.5 \% \mathrm{P}_{2} \mathrm{O}_{5}\right)$ and potassium sulphate $\left(48 \% \mathrm{~K}_{2} \mathrm{O}\right)$.

$\mathrm{N}-$ Fertilization as Ammonium sulphat, $(20.5 \% \mathrm{~N})$ was applied at rates of 0 , 75 and $250 \mathrm{~kg} \mathrm{fed}^{-1}$ in two equal spilt doses 3 and 4 weeks after planting. Plants were sampled after 75 days old to determine number (No.Nod. plant ${ }^{-1}$ ) and dry weight of nodules ( $\mathrm{mg}$ plant $\left.^{-1}\right)$, plant dry weight $\left(\mathrm{g} \mathrm{plant}^{-1}\right)$ and plant nitrogen content (mg plant ${ }^{-1}$ ).
Table 1. Mechanical and chemical analysis of soil

\begin{tabular}{|c|c|}
\hline Analysis & Values \\
\hline Coarse sand \% & 45.11 \\
\hline Fine sand $\%$ & 40.03 \\
\hline Silt \% & 6.45 \\
\hline Clay $\%$ & 8.41 \\
\hline Texture & Sandy loam \\
\hline Calcium carbonate $\%$ & 4.24 \\
\hline $\begin{array}{l}\text { Water holding capacity } \\
\%\end{array}$ & 16.81 \\
\hline $\begin{array}{l}\text { Saturation percentage } \\
\text { (Sp) } \%\end{array}$ & 22.33 \\
\hline $\mathrm{pH}$ & 7.81 \\
\hline E.C. $\left(\mathrm{dSm}^{-1}\right)$ & 1.40 \\
\hline Organic matter $\%$ & 0.55 \\
\hline Total nitrogen $\%$ & 0.011 \\
\hline \multicolumn{2}{|c|}{ Soluble cations (meq L ${ }^{-1}$ ) } \\
\hline $\mathrm{Ca}^{++}$ & 4.20 \\
\hline $\mathrm{Mg}^{++}$ & 2.31 \\
\hline $\mathrm{Na}^{+}$ & 3.99 \\
\hline $\mathrm{K}^{+}$ & 1.80 \\
\hline \multicolumn{2}{|c|}{ Soluble anions $\left(\mathrm{meqL}^{-1}\right)$} \\
\hline $\mathrm{Co}_{3}^{--}$ & 0.00 \\
\hline $\mathrm{HCo}_{3}^{--}$ & 1.0 \\
\hline $\mathrm{Cl}^{-}$ & 2.51 \\
\hline $\mathrm{So}_{4}^{--}$ & 8.79 \\
\hline
\end{tabular}

\section{Field experiment}

Seeds of chickpea variety (Giza 195) at rate of $35 \mathrm{~kg} \mathrm{fed}^{-1}$ were drilled in rows at $20 \mathrm{~cm}$ apart.

Layout (Fig. 2) of 8 treatments with 3 replications in a complete randomized block design. 


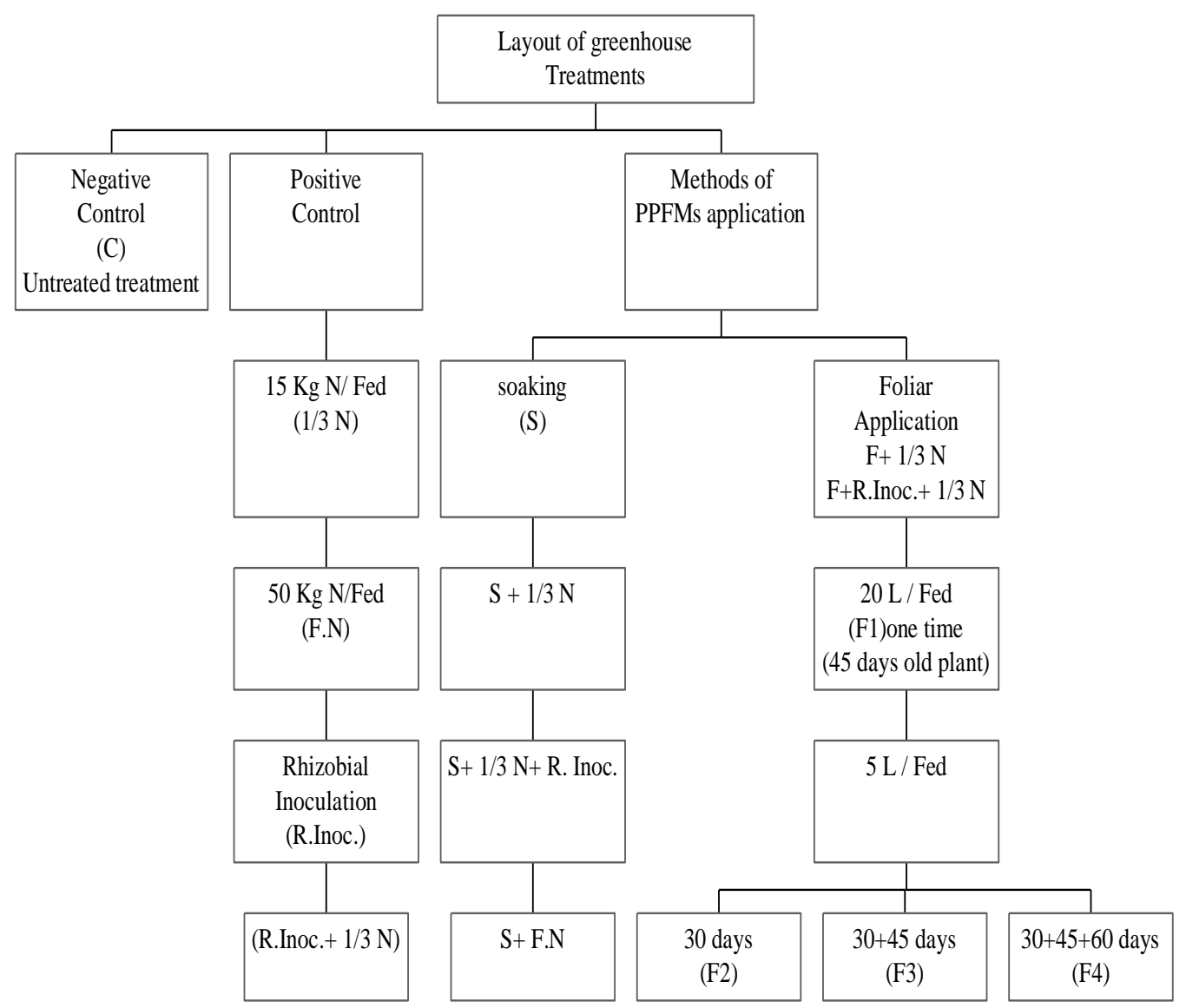

Fig 1. Layout of greenhouse experiments

Arab Univ. J. Agric. Sci., 14(2), 2006 


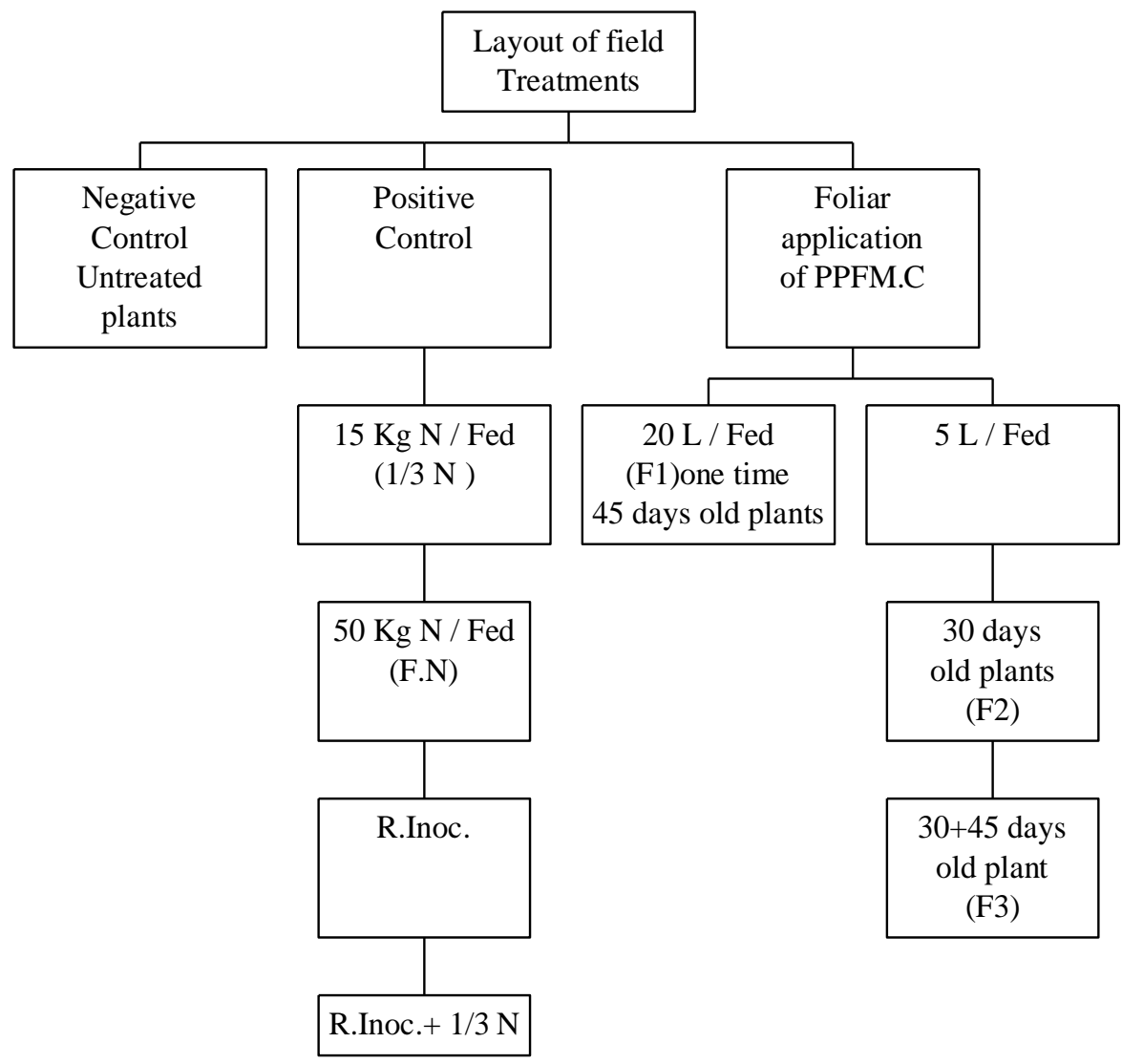

Fig 2. Layout of field experiment.

The recommended doses of $\mathrm{P}$ and $\mathrm{K}$ fertilizers:

$100 \mathrm{Kg}$ superphosphate $\left(15.5 \% \quad \mathrm{P}_{2} \mathrm{O}_{5}\right.$ $\mathrm{fed}^{-1}$ ) and $50 \mathrm{Kg}$ potassium sulphate $\left(48 \% \mathrm{~K}_{2} \mathrm{O}\right.$ fed $\left.^{-1}\right)$ were added to soil, during land preparation, $\mathrm{N}$-fertilization as ammonium sulphate $(20.5 \% \mathrm{~N})$ was applied at the rates of 15 and $50 \mathrm{Kg} \mathrm{N}^{-1}$ added in two equal spilt doses 3 and 4 weeks after planting. The seeds were inoculated with peat based inoculum con- taining rhizobial strains (ICARDA 31 and NIFTAL 1148) specific to chickpea.

Plants were sampled were taken at 60 days old plant to determine number (No. nod.plant $\left.{ }^{-1}\right)$ and dry weight (mg plant $\left.{ }^{-1}\right)$ of nodules, plant dry weight $\left(\mathrm{g}\right.$ plant $\left.{ }^{-1}\right)$ and plant nitrogen content (mg plant ${ }^{-1}$ ). At harvest stage, total biological yield, seed yield $\left(\mathrm{kg} \mathrm{plot}^{-1}\right.$ and $\mathrm{kg} \mathrm{fed}^{-1}$, nitrogen content $(\%)$ at seed and straw and seed index $\left(\mathrm{g} 100\right.$ seeds $\left.^{-1}\right)$ were determined. 


\section{Statistical analysis}

Results were statistically analyzed by the least significant difference test (LSD) at $\mathrm{P}<0.05$ by using MSTAT Microcomputer Statistical Program (Steel and Torrie, 1980).

\section{RESULTS AND DISCUSSION}

\section{Greenhouse experiments}

\subsection{Nodulation status}

Data in Table (2) show the number of nodules and nodules dry weight, untreated treatment and fertilized treatments have no nodules formed. Rhizobial inoculation scored the lowest number and dry weight of nodules for Faba bean and chickpea (28, 15 and 120, $22 \mathrm{mg}$ plant $^{-1}$, respectively). N-Fertilization at rational dose added with inoculation led to significant increases in both nodules number and nodules dry weight and such increases ranged between 54-40\% and 57-41\% in same order as compared to inoculated ones.

PPFMs inoculation used as soaking in presence of $15 \mathrm{Kg} \mathrm{N} \mathrm{Fed}^{-1}$ and rhizobial inoculation of two legume crops used gave significant increases in both number and dry weight of nodules as compared with rhizobial inoculation as such and ranged from $53-57 \%$ for nodules number and $55-63 \%$ for nodules dry weight.

Foliar application of PPFMs at rate 20L Fed ${ }^{-1}$ one time (45 days old plant)recorded no significant increases as compared to inoculated treatment +15 $\mathrm{Kg} \mathrm{N} \mathrm{Fed}^{-1}$ and/or PPFMs soaking treatment in case of chick pea plant. In con- trast, faba bean plants showed an positive trend.

Foliar inoculation with PPFMs at application rate $5 \mathrm{~L} \mathrm{Fed}^{-1}$ in presence of 15 $\mathrm{Kg} \mathrm{N} \mathrm{Fed}^{-1}$ and rhizobial inoculation emphasized the superiority of twice treatment at 30 and 45 days from planting against one or three times ones. Moreover, the above-mentioned treatment recorded the highest number of nodules (3049 plant $^{-1}$ ) and nodules dry weight (45$220 \mathrm{mg} \mathrm{plant}^{-1}$ ) for chickpea and faba bean, respectively.

Irrespective to the rates and times of applied foliar inoculation of PPFMs, soaking in PPFMs recorded higher values for both number and dry weight of nodules (44 and 196) against foliar application $(42,174)$ in case of faba bean plants. In case of chickpea plants foliar application exhibited a positive effect and recorded higher increase ranged from 10 to $13 \%$ against soaking treatment in the same two tested parameters.

These results could be attributed to that the ability of the inoculation with PPFMs strains as helper bacteria to release cytokinin, which play a role in increasing the nodulation of both plants.

These results are in agreement with Truchet et al (1984); Holland (1997b); Joshi et al (2000) and Stougaard (2000) who reported that PPFMs plays very important role in root nodule initiation, development and function of many legume plants, i.e. alfa alfa and soybean.

\subsection{Dry weight and N-content}

Data presented in Table (3) show that high significant differences in plant dry weight and plant $\mathrm{N}$-content were evident among treatments. 
Table 2. Effect of PPFM bacterial strains (PPFM.F \& PPFM.C), Rhizobium inoculation and $\mathrm{N}$-fertilization on nodulation status of faba bean and chickpea plants grown in greenhouse ( 75 days old plant)

\begin{tabular}{|c|c|c|c|c|}
\hline \multirow[b]{2}{*}{ Treatment } & \multicolumn{2}{|c|}{ Faba bean } & \multicolumn{2}{|c|}{ Chickpea } \\
\hline & $\begin{array}{l}\text { No .of no- } \\
\left.\text { dules (plant }{ }^{-1}\right)\end{array}$ & $\begin{array}{c}\text { Dry weight of } \\
\text { nodules } \\
\left(\mathrm{mg} \mathrm{plant}^{-1}\right)\end{array}$ & $\begin{array}{l}\text { No .of } \\
\text { nodules } \\
\left.\text { (plant }^{-1}\right)\end{array}$ & $\begin{array}{c}\text { Dry weight of } \\
\text { nodules } \\
\left(\mathrm{mg} \mathrm{plant}^{-1}\right)\end{array}$ \\
\hline $\mathrm{T}_{1} \mathrm{C}$ & 0 & 0 & 0 & 0 \\
\hline $\mathrm{T}_{2} 1 / 3 \mathrm{~N}$ & 0 & 0 & 0 & 0 \\
\hline $\mathrm{T}_{3}$ F.N & 0 & 0 & 0 & 0 \\
\hline $\mathrm{T}_{4} \mathrm{R}$. Inoc. & 28 & 120 & 15 & 22 \\
\hline $\mathrm{T}_{5}$ R. Inoc. $+1 / 3 \mathrm{~N}$ & 43 & 188 & 21 & 31 \\
\hline $\mathrm{T}_{6} \mathrm{~S}+1 / 3 \mathrm{~N}$ & 0 & 0 & 0 & 0 \\
\hline $\mathrm{T}_{7} \mathrm{~S}+$ R.Inoc. $+1 / 3 \mathrm{~N}$ & 44 & 196 & 23 & 34 \\
\hline $\mathrm{T}_{8} \mathrm{~S}+\mathrm{F} . \mathrm{N}$ & 0 & 0 & 0 & 0 \\
\hline $\mathrm{T}_{9} \mathrm{~F} 1+1 / 3 \mathrm{~N}$ & 0 & 0 & 0 & 0 \\
\hline $\mathrm{T}_{10} \mathrm{~F} 1+$ R.Inoc. $+1 / 3 \mathrm{~N}$ & 39 & 139 & 24 & 37 \\
\hline $\mathrm{T}_{11} \mathrm{~F} 2+1 / 3 \mathrm{~N}$ & 0 & 0 & 0 & 0 \\
\hline $\mathrm{T}_{12} \mathrm{~F} 2+$ R.Inoc. $+1 / 3 \mathrm{~N}$ & 39 & 146 & 23 & 28 \\
\hline $\mathrm{T}_{13} \mathrm{~F} 3+1 / 3 \mathrm{~N}$ & 0 & 0 & 0 & 0 \\
\hline $\mathrm{T}_{14} \mathrm{~F} 3+$ R.Inoc. $+1 / 3 \mathrm{~N}$ & 49 & 220 & 30 & 45 \\
\hline $\mathrm{T}_{15} \mathrm{~F} 4+1 / 3 \mathrm{~N}$ & 0 & 0 & 0 & 0 \\
\hline $\mathrm{T}_{16} \mathrm{~F} 4+$ R.Inoc. $+1 / 3 \mathrm{~N}$ & 41 & 192 & 27 & 40 \\
\hline L.S.D. ${ }_{0.05}$ & 5 & 15.7 & 5 & 8.2 \\
\hline $\begin{array}{l}\text { T: Treatment } \\
\text { C: Control (untreated treat } \\
1 / 3 \mathrm{~N}: 15 \mathrm{Kg} \mathrm{N} \mathrm{Fed}^{-1} \\
\mathrm{~S}: \text { Soaking treatment } \\
\mathrm{F}_{1}: \text { Foliar application } 20 \mathrm{~L} \\
\mathrm{~F}_{2}: \text { Foliar application } 5 \mathrm{~L} \\
\mathrm{~F}_{3}: \text { Foliar application } 5 \mathrm{~L} \mathrm{I} \\
\mathrm{F}_{4}: \text { Folar application } 5 \mathrm{~L} \mathrm{~F}\end{array}$ & 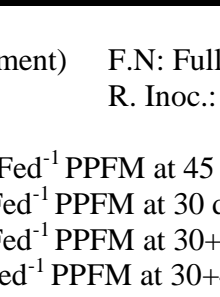 & $\begin{array}{l}\text { Nitrogen }(50 \mathrm{Kg} \\
\text { hizobial inoculat } \\
\text { ays from plantin } \\
\text { ys from planting } \\
5 \text { days from plan } \\
5+60 \text { days from }\end{array}$ & $\left.\mathrm{ed}^{-1}\right)$ & \\
\hline
\end{tabular}

The untreated treatment recorded the lowest values of plant dry weight $(5.20$ and 0.45$)$ and plant $\mathrm{N}$-content (109 and $5.32 \mathrm{mg} \mathrm{plant}^{-1}$ ) in faba bean and chickpea plants respectively.
The percentage significant increases of plant dry weight and plant $\mathrm{N}$-content among various treatments as compared to untreated ones also found in Table (3). 
Table 3. Effect of PPFM bacterial strains (PPFM.F \&PPFM.C), Rhizobium inoculation and $\mathrm{N}$-fertilization on plant dry weight, $\mathrm{N}$-content and percentage of increases of faba bean and chickpea plants grown in greenhouse ( 75 days old plant)

\begin{tabular}{|c|c|c|c|c|c|c|c|c|}
\hline \multirow[b]{2}{*}{ Treatment } & \multicolumn{4}{|c|}{ Faba bean } & \multicolumn{4}{|c|}{ Chickpea } \\
\hline & $\begin{array}{c}\text { Plant } \\
\text { dry } \\
\text { weight }\end{array}$ & $\begin{array}{c}\% \\
\text { increase }\end{array}$ & $\begin{array}{c}\mathrm{N} \\
\text { content }\end{array}$ & $\begin{array}{l}\% \text { in- } \\
\text { crease }\end{array}$ & $\begin{array}{c}\text { Plant } \\
\text { dry } \\
\text { weight }\end{array}$ & $\begin{array}{c}\% \\
\text { increase }\end{array}$ & $\begin{array}{l}\mathrm{N} \text { con- } \\
\text { tent }\end{array}$ & $\begin{array}{c}\% \\
\text { increase }\end{array}$ \\
\hline $\mathrm{T}_{1} \mathrm{C}$ & 5.20 & - & 109 & - & 0.45 & - & 5.32 & - \\
\hline $\mathrm{T}_{2} 1 / 3 \mathrm{~N}$ & 6.60 & 27 & 203 & 86 & 0.49 & 9 & 6.57 & 23 \\
\hline $\mathrm{T}_{3} \mathrm{~F} . \mathrm{N}$ & 14.50 & 179 & 415 & 281 & 1.04 & 13 & 18.63 & 250 \\
\hline $\mathrm{T}_{4} \mathrm{R}$. Inoc. & 8.03 & 54 & 244 & 124 & 0.64 & 42 & 8.63 & 62 \\
\hline $\mathrm{T}_{5} \mathrm{R}$. Inoc. $+1 / 3 \mathrm{~N}$ & 10.50 & 102 & 284 & 160 & 0.67 & 49 & 9.11 & 71 \\
\hline $\mathrm{T}_{6} \mathrm{~S}+1 / 3 \mathrm{~N}$ & 6.8 & 31 & 199 & 82 & 0.66 & 47 & 9.49 & 78 \\
\hline $\begin{array}{c}\mathrm{T}_{7} \mathrm{~S}+\mathrm{R} \text {.Inoc. } \\
+1 / 3 \mathrm{~N}\end{array}$ & 10.30 & 98 & 310 & 184 & 0.73 & 62 & 11.38 & 114 \\
\hline $\mathrm{T}_{8} \mathrm{~S}+\mathrm{F} \cdot \mathrm{N}$ & 13.40 & 158 & 414 & 280 & 0.66 & 47 & 10.20 & 92 \\
\hline $\mathrm{T}_{9} \mathrm{~F} 1+1 / 3 \mathrm{~N}$ & 8.33 & 60 & 259 & 138 & 0.76 & 69 & 12.24 & 130 \\
\hline $\begin{array}{c}\mathrm{T}_{10} \mathrm{~F} 1+\mathrm{R} \text {.Inoc. } \\
+1 / 3 \mathrm{~N}\end{array}$ & 12.50 & 140 & 361 & 231 & 0.81 & 80 & 13.05 & 145 \\
\hline $\mathrm{T}_{11} \mathrm{~F} 2+1 / 3 \mathrm{~N}$ & 8.37 & 61 & 299 & 174 & 0.81 & 80 & 13.30 & 150 \\
\hline $\begin{array}{c}\mathrm{T}_{12} \mathrm{~F} 2+\mathrm{R} . \text { Inoc } \\
+1 / 3 \mathrm{~N}\end{array}$ & 14.00 & 169 & 412 & 278 & 0.82 & 82 & 14.30 & 169 \\
\hline $\mathrm{T}_{13} \mathrm{~F} 3+1 / 3 \mathrm{~N}$ & 12.80 & 146 & 388 & 256 & 0.86 & 91 & 15.02 & 182 \\
\hline $\begin{array}{c}\mathrm{T}_{14} \mathrm{~F} 3+\mathrm{R} \text {.Inoc. } \\
+1 / 3 \mathrm{~N}\end{array}$ & 13.70 & 163 & 411 & 277 & 0.87 & 93 & 15.10 & 184 \\
\hline $\mathrm{T}_{15} \mathrm{~F} 4+1 / 3 \mathrm{~N}$ & 13.03 & 151 & 42.3 & 288 & 0.89 & 97 & 15.66 & 194 \\
\hline $\begin{array}{l}\mathrm{T}_{16} \mathrm{~F} 4+\mathrm{R} \text {.Inoc. } \\
+1 / 3 \mathrm{~N}\end{array}$ & 14.90 & 187 & 487 & 347 & 1.10 & 144 & 19.14 & 260 \\
\hline L.S.D. 0.05 & 1.44 & & 61.27 & & 0.24 & & 4.24 & \\
\hline
\end{tabular}

T: Treatment

Plant dry weight: $\left(\mathrm{g}\right.$ plant $\left.{ }^{-1}\right)$.

$\%$ of increase $=\mathrm{T}_{\mathrm{x}}-\mathrm{T}_{1} / \mathrm{T}_{1} \times 100$

Plant N-content: $\left(\mathrm{mg}\right.$ plant $\left.^{-1}\right)$.

$\mathrm{x}$ : number of any treatment 
A part from levels of $\mathrm{N}$-fertilization, rates and times of applied foliar inoculation of PPFMs, data presented in Table (4) show that the mean plant dry weight of $\mathrm{N}$-fertilized, soaking application of PPFMs and foliar application of faba bean and chick pea plants increased by 14, 10 and $31 \%$ for faba bean and 17, 3 and $32 \%$ for chickpea plants against rhizobial inoculated treatments. The corresponding percentages of plants $\mathrm{N}$-content were 17,7 and $44 \%$ for faba bean and 42 , 17 and $66 \%$ for chickpea plants in the same order. Moreover foliar application of PPFMs increased plant dry weight (20 and $28 \%$ ) and plant $\mathrm{N}$-content (23 and $42 \%)$ against soaking application treatments for faba bean and chickpea plants, respectively.

Under greenhouse conditions inoculation of faba bean and chickpea plants with respective PPFMs significantly improved nodule status, plant growth and plant N-content, especially when the foliar inoculation with both strains of PPFMs was used. Inoculation with rhizobial strains and foliar application of PPFM strains combined with reasonable dose of $\mathrm{N}$-fertilizer gave the best results comparing to the other treatments, specially the inoculation with rhizobial strains to the same $\mathrm{N}$-fertilizer treatment.

This result could be attributed to the role of the PPFM strains as helper bacteria in stimulating symbiosis system between Rhizobium spp. and the legume plants.

These data were in harmony with those obtained from different reports; Corpe and Basile (1982) who reported that PPFMs stimulate seed germination and plant development.

Holland (1997a) stated that, the activities of the PPFMs could make a biochemically measurable and physiologically meaningful contribution to plant metabolism. Holland (1997b) reported that, application of inoculation with PPFMs resulted increasing of plant dry weight of soybean plants as compared to untreated ones.

Omer (2004) revealed that PPFMs produced cytokinin and other phytohormones, which stimulate the plant growth and development.

Table 4. Increase of plant dry weight and plant N-content of faba bean and chickpea plants grown in greenhouse as affected by $\mathrm{N}$ - fertilization and PPFMs bacterial strains

\begin{tabular}{|lccccccccc|}
\hline \multirow{2}{*}{ Parameter } & \multicolumn{4}{c}{ Faba bean } & \multicolumn{5}{c|}{ Chickpea } \\
\cline { 2 - 10 } & \multicolumn{2}{c}{$\begin{array}{c}\text { Plant dry } \\
\text { weight }\end{array}$} & \multicolumn{2}{c}{ N-content } & Plant dry weight & N-content \\
\cline { 2 - 10 } Treatment & g plant $^{-1}$ & $\%$ & mg plant $^{-1}$ & $\%$ & g plant $^{-1}$ & $\%$ & mg plant $^{-1}$ & $\%$ \\
\hline *R.Inoc. & 9.27 & - & 264 & - & 0.66 & - & 8.87 & - \\
N-Fertilization & 10.55 & 14 & 309 & 17 & 0.77 & 17 & 12.60 & 42 \\
Soaking PPFMs & 10.17 & 10 & 308 & 17 & 0.68 & 3 & 10.36 & 17 \\
Foliar PPFMs & 12.19 & 31 & 380 & 44 & 0.87 & 32 & 14.73 & 66 \\
\hline
\end{tabular}

* Rhizobial inoculation 


\section{Field experiment}

\subsection{Growth stage}

\subsubsection{Number and dry weight of no- dules}

Data in Table (5) revealed that, the untreated treatment recorded the lowest nodules number and dry weight and these values were, 8 No plant $^{-1}$ and $19 \mathrm{mg}$ plant $^{-1}$, respectively.

Application of $\mathrm{N}$-fertilization achieved no significant differences in two tested parameters as compared to untreated ones.

Inoculation with specific Rhizobium scored higher significant increases as compared to the treatments fertilized with $15 \mathrm{~kg} \mathrm{~N} \mathrm{Fed}^{-1}$, in both nodules number (59-12) by 4 and nodules dry weight (252-25 mg plant ${ }^{-1}$ ) by 9 -folds.

No significant increases were found in case of foliar application with PPFM.C at rate $20 \mathrm{~L}^{-\mathrm{Fed}^{-1}}$ (45 days from planting) in both nodules number and nodules dry weight as compared to inoculated plants with specific Rhizobium combined with $15 \mathrm{~kg} \mathrm{~N} \mathrm{Fed}^{-1}$.

Table 5. Nodulation status, plant dry matter and plant N-content of chickpea plants as affected by $\mathrm{N}$-fertilization, Rhizobial inoculation and foliar inoculation of strain PPFM.C (60 days old plant) grown under field conditions

\begin{tabular}{|lcccc|}
\hline \multicolumn{1}{|c}{ Parameters } & $\begin{array}{c}\text { No. } \\
\text { of nodules } \\
\left(\text { plant }^{-1}\right)\end{array}$ & $\begin{array}{c}\text { Dry weight } \\
\text { nodules } \\
\text { Treatments }\end{array}$ & $\begin{array}{c}\text { Plant } \\
\text { dry matter }\end{array}$ & $\begin{array}{c}\text { Plant } \\
\text { N-content }\end{array}$ \\
\hline Control & 8 & 19 & 1.80 & 22.51 \\
$15 \mathrm{~kg} \mathrm{~N} \mathrm{Fed}^{-1}$ & 12 & 25 & 2.70 & 57.93 \\
50 kg N Fed & -1
\end{tabular}

$\mathrm{C}$ : Control (untreated treatment)

R.Inoc.: Rhizobial inoculation

$\mathrm{F}_{1}$ : Foliar application of PPFM.C at rate $20 \mathrm{~L} \mathrm{Fed}^{-1}$ (45 days from planting)

$\mathrm{F}_{2}$ : Foliar application of PPFM at rate $5 \mathrm{~L} \mathrm{Fed}^{-1}$ (30 days from planting )

$\mathrm{F}_{3}$ : Foliar application of PPFM at rate $5 \mathrm{~L} \mathrm{Fed}^{-1}(30+45$ days from planting $)$ 
Application of PPFM.C at rate $5 \mathrm{~L}$ $\mathrm{Fed}^{-1}$ (30 and 45 days old plant) caused significant difference for nodules number as compared to inoculated and fertilized chickpea plants.

Moreover, PPFM.C at rate $5 \mathrm{~L} \mathrm{Fed}^{-1}$ (30 and 45 days old plant) scored significant increases as compared to applied PPFM.C at rate $20 \mathrm{~L} \mathrm{Fed}^{-1}$ (45 days old plant); such increases were $36 \%$ (121-89) for nodule number and 34\% (401-300 mg plant $\left.^{-1}\right)$, for nodules dry weight.

\subsubsection{Dry matter and N-content}

As shown in Table (5) inoculation of chickpea plants enhanced plant growth and increased their $\mathrm{N}$-contents, however it showed significant positive variations as compared to fertilized plants with 15 $\mathrm{Kg} \mathrm{N} \mathrm{Fed}^{-1}$.

Application of PPFM.C at rate $5 \mathrm{~L}$ $\mathrm{Fed}^{-1}$ (30 and 45 days from planting) caused significant increases as compared to applied PPFM.C at rate $20 \mathrm{~L} \mathrm{Fed}^{-1}$ (45 days old plants) and such increases were $9 \%$ for plant dry matter and $20 \%$ for plant $\mathrm{N}$-content. In conclusion the foliar application of the PPFM strain combined with the inoculation with Rhizobium sp. inoculation and soil amendment with $15 \mathrm{Kg} \mathrm{N}$ $\mathrm{Fed}^{-1}$ (the reasonable dose) increased plant dry weight and nitrogen content of chickpea plants after 60 days compared to the same treatment without PPFM application. The bi-application of the helper bacteria (PPFM.C strain) after 30 and 45 days gave significant increase in plant dry weight and nitrogen content.

The above mentioned results are in agreement to Corpe \& Basile (1982); Truchet et al (1984); Holland (1997 a\&b) and Omer (2004) who reported that PPFM bacteria enhanced nodule formation, plant growth and development and play very important role in plant nitrogen content.

\subsection{Harvest stage}

Table (6) presents total biological yield and seed yield $\left(\mathrm{Kg}_{\mathrm{plot}}{ }^{-1}\right.$ \& $\mathrm{Kg}$ $\left.\mathrm{Fed}^{-1}\right)$ seed index $\left(\mathrm{g} 100 \mathrm{seed}^{-1}\right)$, nitrogen and protein percentage for both straw and seed of chickpea crop of the various treatments. Application of $50 \mathrm{Kg} \mathrm{N} \mathrm{Fed}{ }^{-1}$ treatment markedly recorded significant increases in total biological yield as compared to untreated and inoculated chickpea plants combined with or without 15 $\mathrm{Kg} \mathrm{N} \mathrm{Fed}^{-1}$ and such increases were, 115, 97,81 and $33 \%$ for untreated ones, rational dose $\left(15 \mathrm{Kg} \mathrm{N} \mathrm{Fed}^{-1}\right)$, inoculated plant and fertilized with $15 \mathrm{KgN} \mathrm{Fed}{ }^{-1}$, respectively.

The corresponding percentages increases for seed yield $\mathrm{Kg} \mathrm{plot}^{-1}$ were 173, 99, 93 and $16 \%$ in the same order. Strain PPFM.C applied at rate 20L Fed ${ }^{-1}$ supported exceptional seed yield $(0.581 \mathrm{Kg}$ plot $^{-1}$ ) for fertilized plant (50 Kg Fed ${ }^{-1}$ ) and inoculated plants and fertilized with $\left(15 \mathrm{Kg} \mathrm{N} \mathrm{Fed}^{-1}\right.$ ) with respective increases of 20 and 39\%, respectively.

The highest seed yield $(0.617 \mathrm{Kg}$ plot $^{-1}$ ) was obtained by PPFM.C at rate of $5 \mathrm{~L} \mathrm{Fed}^{-1}$ (30 and 45 days from planting) against 20 $\mathrm{L} \mathrm{Fed}^{-1}$ (45 days old plants) for seed yield, $\left(0.581 \mathrm{Kg} \mathrm{plot}^{-1}\right)$.

In respect to the main effect of PPFM.C, different levels (Table 6) on seed yield $\left(\mathrm{Kg} \mathrm{Fed}^{-1}\right)$, results that the seed yield $\left(\mathrm{Kg} \mathrm{Fed}^{-1}\right)$ of chickpea plants increased obviously with increasing the applied different levels from PPFM.C.

The same trend was obtained at seed index $\left(\mathrm{g} 100 \mathrm{seed}^{-1}\right)$. 
Table 6. Yield parameters of chickpea as affected by $\mathrm{N}$-fertilization, rhizobial inoculation and foliar application of PPFM.C strain grown under field conditions

\begin{tabular}{|c|c|c|c|c|c|c|c|}
\hline \multirow[b]{2}{*}{ Treatments } & \multicolumn{2}{|c|}{$\begin{array}{l}\text { Total biologi- } \\
\text { cal yield }\end{array}$} & \multicolumn{2}{|c|}{ Seed yield } & \multirow{2}{*}{$\begin{array}{c}\text { Seed } \\
\text { index } \\
(\mathrm{g} 100 \\
\left.\text { seed }^{-1}\right)\end{array}$} & \multirow{2}{*}{$\begin{array}{c}\text { Seed } \\
\text { protein } \\
\%\end{array}$} & \multirow{2}{*}{$\begin{array}{c}\text { Straw } \\
\mathrm{N}- \\
\text { content } \%\end{array}$} \\
\hline & $\begin{array}{c}\mathrm{Kg} \\
\operatorname{plot}^{-1}\end{array}$ & $\begin{array}{c}\mathrm{Kg} \\
\mathrm{Fed}^{-1}\end{array}$ & $\begin{array}{c}\mathrm{Kg} \\
\operatorname{plot}^{-1}\end{array}$ & $\begin{array}{c}\mathrm{Kg} \\
\mathrm{Fed}^{-1}\end{array}$ & & & \\
\hline Control & 0.80 & 672 & 0.177 & 149 & 15.73 & 24.51 & 1.57 \\
\hline $15 \mathrm{Kg} \mathrm{N} \mathrm{Fed}^{-1}$ & 0.870 & 731 & 0.243 & 204 & 18.60 & 25.92 & 1.71 \\
\hline $50 \mathrm{Kg} \mathrm{N} \mathrm{Fed}^{-1}$ & 1.717 & 1442 & 0.484 & 407 & 20.10 & 26.19 & 1.83 \\
\hline R.Inoc. & 0.950 & 798 & 0.251 & 211 & 17.87 & 26.19 & 1.88 \\
\hline R.Inoc. $+15 \mathrm{Kg} \mathrm{N} \mathrm{Fed}^{-1}$ & 1.295 & 1084 & 0.419 & 352 & 18.47 & 26.29 & 1.91 \\
\hline $\mathrm{F}_{1}+$ R.Inoc. $+15 \mathrm{~K} \mathrm{NFed}^{-1}$ & 1.547 & 1299 & 0.581 & 488 & 19.50 & 26.22 & 1.94 \\
\hline $\mathrm{F}_{2}+$ R.Inoc. $+15 \mathrm{Kg} \mathrm{NFed}^{-1}$ & 1.800 & 1512 & 0.604 & 507 & 19.73 & 26.31 & 1.98 \\
\hline $\mathrm{F}_{3}+$ R.Inoc. $+15 \mathrm{Kg} \mathrm{NFed}^{-1}$ & 2.083 & 1750 & 0.617 & 518 & 20.13 & 26.35 & 2.01 \\
\hline L.S.D $D_{0.05}$ & 0.417 & 243 & 0.037 & 51 & n.s & - & - \\
\hline
\end{tabular}

C: Control (untreated treatment)

R. Inoc.: Rhizobial inoculation

$\mathrm{F}_{1}$ : Foliar application of PPFM.C at rate $20 \mathrm{~L} \mathrm{Fed}^{-1}$ (45 days from planting)

$\mathrm{F}_{2}$ : Foliar application of PPFM at rate $5 \mathrm{~L} \mathrm{Fed}^{-1}$ (30 days from planting)

$\mathrm{F}_{3}$ : Foliar application of PPFM at rate $5 \mathrm{~L} \mathrm{Fed}^{-1}(30+45 \mathrm{~d}$ days from planting)

Moreover, the highest values $(20.13 \mathrm{~g}$ 100 seed $^{-1}$ ) were obtained by PPFM.C at rate $5 \mathrm{~L} \mathrm{Fed}^{-1}$ (30 and 45 days old plants).

Variations in percentage of seed protein content among the different treatments were comparable to those recorded with straw N-content. The lowest seed protein content and straw $\mathrm{N}$-content (24.51 and $1.57 \%$ ) were recorded for untreated plants. Increases up to 8 and $28 \%$ for seed protein content and straw $\mathrm{N}$ content, respectively, were attributed to PPFM.C application.

The obtained data are in agreement to land (1997b) they reported that the activities of PPFMs could make a biochemically measurable and physiologically meaning full contribution to plant nitrogen accumulation and metabolism.

Again, the highest yield and yield components of chickpea were obtained by intensive inoculation (Rhizobium and PPFM.C at rate $5 \mathrm{~L} \mathrm{Fed}^{-1,} 30$ and 45 days from planting) in presence of $15 \mathrm{Kg} \mathrm{N}$ $\mathrm{Fed}^{-1}$. In this respect, Joshi et al (2000) suggested that the use of PPFMs inocula as biofertilizer in soybean production in arid environments. 


\subsection{Economic turnover}

The economic management of desert soil (South El Tahreer) requires complementation of intensive bacterial inoculation (Rhizobium + PPFM.C) together with adequate regime of $\mathrm{N}$-fertilization. As shown in Table (7) inoculated plants and combined with $15 \mathrm{Kg} \mathrm{N} \mathrm{Fed}^{-1}$ recorded the lowest economic return (1711 L.E) and decreased by $9 \%$ as compared to fertilized plant with $50 \mathrm{Kg} \mathrm{N} \mathrm{Fed}^{-1}$. Irrespective to PPFM.C amount and times of application, PPFM.C led to increases in yield economic return and such increases ranged from 21 to $32 \%$ as compared to applied $50 \mathrm{Kg} \mathrm{N} \mathrm{Fed}^{-1}$ treatment.

Table 7. Economic turnover of chickpea yield as affected with various treatments

\begin{tabular}{|c|c|c|c|c|}
\hline $\begin{array}{l}\text { Parameters } \\
\text { Treatments }\end{array}$ & $\begin{array}{l}\text { Cost } \\
\text { (L.E) }\end{array}$ & $\begin{array}{l}\text { Yield } \\
(\mathrm{Kg} \\
\left.\mathrm{fed}^{-1}\right)\end{array}$ & $\begin{array}{c}\text { Economic } \\
\text { return } \\
\text { (L.E) }\end{array}$ & $\begin{array}{c}\text { Increases } \\
(\%)\end{array}$ \\
\hline $\begin{array}{l}\text { fertilization } \\
50 \mathrm{KgNfed}^{-1}\end{array}$ & 150 & 407 & 1885 & - \\
\hline $\begin{array}{l}\text { R.Inoc. }+15 \\
\mathrm{Kg} \mathrm{N} \mathrm{fed}^{-1}\end{array}$ & 49 & 352 & 1711 & -9 \\
\hline $\begin{array}{l}\mathrm{F}_{1}+\mathrm{R} \text {.Inoc. } \\
+15 \mathrm{Kg} \mathrm{N} \\
\text { fed }^{-1}\end{array}$ & 149 & 488 & 2286 & +21 \\
\hline $\begin{array}{l}\mathrm{F}_{2}+\text { R.Inoc. }+ \\
15 \mathrm{Kg} \mathrm{N} \mathrm{fed}^{-1}\end{array}$ & 74 & 507 & 2461 & +31 \\
\hline $\begin{array}{l}\mathrm{F}_{3}+\text { R.Inoc. }+ \\
15 \mathrm{Kg} \mathrm{N} \mathrm{fed}^{-1}\end{array}$ & 99 & 518 & 2491 & +32 \\
\hline
\end{tabular}

According to commercial market (2005):

$\mathrm{N}\left(\mathrm{Kg} \mathrm{fed}^{-1}\right)=3.0$ L.E

R. Inoc. $=4.0 \mathrm{~L} . \mathrm{E}$

PPFM.C L ${ }^{-1}=5.0$ L.E

Ton (seed) of chickpea $=5000$ L.E

From the present work it could be concluded that, pot and field experiments demonstrated that, under sandy loam soil conditions, necessity exists for inoculation with symbiotic $\mathrm{N}_{2}$-fixing bacteria and PPFMs as plant growth promoting bacteria to maximize the development and yield production of tested legumes.

Under Egyptian field conditions, PPFMs did support nodulation, biological nitrogen fixation process, plant growth and plant yield component. The highest yield was obtained, when rhizobial inoculation, foliar PPFMs application and 15 $\mathrm{kg} \mathrm{N}$ fed $^{-1}$ were applied. In economic terms, PPFMs demonstrated (2491 L.E) gains in seed yield productivity.

\section{REFERENCES}

Arshad, M. and W.T. Jr. Frankenberger (1998). Plant growth substances in rhizosphere: microbial production and functions. Adv. Agron. 62: 46-151.

Corpe, W.A. and D.V. Basile (1982). Methanol utilizing bacteria associated with green plants. Dev. Indust. Microbiol. 23: 483-493.

Frankenberger, Jr. W.T. and M. Arshad (1995). Phytohormons in Soils; Microbial Production and Function, pp. 110, Marcel Dekker, Inc., New York

Holland, M.A. (1997a). Are cytokinins produced by plants? Plant Physiol. 115: 865-868.

Holland, M.A. (1997b). Methylobacterium and plants. Recent Res. Devel. in Plant Physiol. 1: 207-213.

Holland, M.A. and J.C. Polacco (1994). PPFMs and other covert contaminant: is there more to plant physiology than just plant. Ann. Rev. Plant Physiol. Plant Mol. Bio. 45: 197-209. 
Jackson, M.I. (1973). Soil Chemical Analysis, pp. 16-18. Constable and Co., Ltd. London.

Joshi, J.; S.A. Mahmoud; M.A. Holland; E.M. Minsmje; R.B. Dadson; M.A. Omer; F.M. Hashem and S.M. Abdel-wahab (2000). PPFMs;Are these the future biofertilizers? Proc. $12^{\text {th }} \mathrm{An}$ nual Agronomy Society Meeting, pp. 2431. Dt-lous, Mo. USA.

Lidstorm, M.E. (2002). Plants in the pink: Cytokinin production by Methylobacterium, J. Bacteriol., 184 (7):1818.

Omer, Z.S. (2004). Bacterial Plant Associations with Special Focus on Pink Pigmented Facultative Methylotrophic Bacteria (PPFMs), pp. 25-30. Ph.D. Thesis. Plant Pathology Dept. Biocontrol Unit. Agriculture Fac., Suecia Univ., Algaria

Orf, Heba O.M.; Wedad, E.E. Eweda; Sawsan, F. Shehata and H.H. Abo Taleb (2005). Isolation, purification and identification of some microorganisms produce plant growth promoting sub- stances (methylotrophic bacteria). Arab Univ. J. Agric. Sci. Ain Shams, Univ., Cairo, 13 (3):717-729.

Polacco, J.C. and M.A. Holland (1994). Roles of urease in plant cells. Int. Rev. Cytol. 145:65-103.

Steel, R.G.B. and J.H. Torrie (1980). Principles and Procedures of Statistics. $A$ Biometric Approach, $2^{\text {nd }} \mathrm{Ed}$. McGrawHill, New York.

Stougaard, J. (2000). Regulators and regulation of legume root nodule development. Plant Physiol., 124: 531-540.

Truchet, G.; C. Rosenberg; J. Vass; J. Julliot; S. Camut and J. Denarie (1984). Transfer of Rhizobium meliloti PSYM into Agrobacterium tumefaciens: Host- specific nodulation by a typical infection. J. Bacteriol. 157: 134-142. Vincent, J.M. (1970). A Manual for the Practical Study of the Root Nodule Bacteria. In: International, Biological Programme. Handbook. No. 15. pp. 75-76. Blackwell Scientific Publications, Oxford and Edinburgh. U.K. 


\section{بحلة اتحاد الجامعات العربية للدراسات والبحوث الزراعية، جامعة عين شمس، القاهرة، 14(2)، 625-639، 2006}

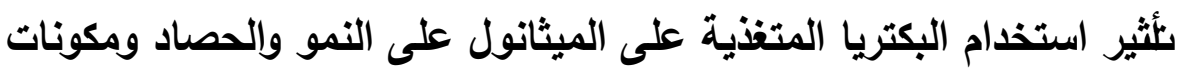
المحصول لتباتاث الحمص والفول البلدى

[40]

سوسن فوزى شحاته 1- حاتم حسين يوسف أبوطالب²- وداد التهامى السبد عويضة هبه عرف محمد عرف 2

1- قسم الميكرو بيولوجيا الزراعية- كلية الزراعة- جامعة عين شمس - شبرا الخيمة- القاهرة- مصر

2- قسم الميكرو بيولوجيا الزراعية- معهد بحوث الأراضى والمياة والبيئة- مركز البحوث الزراعية- الجيزة-

بعزلةPPFM.C والتلقيح بالريزوبيا المتخصصة

في وجود التسميد النيتروجيني بمعدل 15

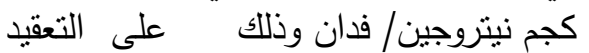
والنمو والمحتوى النيتروجينى وأيضنا على نلى

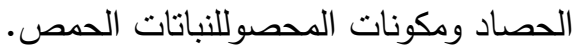

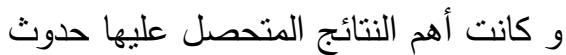
زيادة معنوية فى العائد الاقتصادى للحمص النص

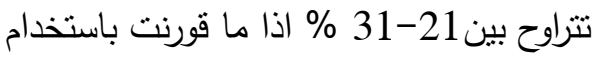
التسميد المعدنى بمعدل 50 كم نيتروجين /فدان. أظهر استخدام الرش بمزارع PPFM.C التلقيح بالريزوبيا المتخصصة والتسميد

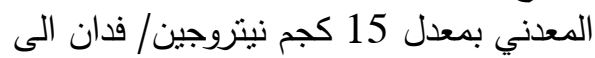
تعظيم الناتج المحصولي (518 كجم / فدان) وزيادة العائد الاقتصادي للحمص ( 2491 ج•م) و تقليل التلوث الناتج عن استخدام التسميد المعدني في الزراعة المستدامة.

$$
\text { أجريت تجربتى صوبة بمركز البحوث }
$$

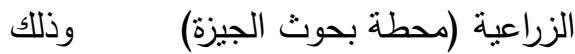

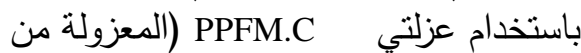

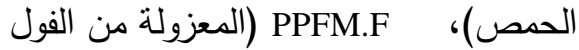

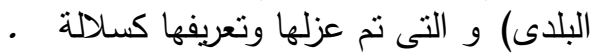
و Methylobacterium radiotolerans Sما نشر فى بحث آخر M. mesophilicum وذلك بهدف دراسة العلاقة بين البكتريا المتغذية على الميثانول والنباتات البقولية

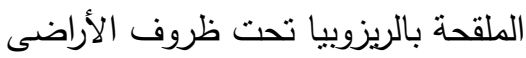
المصرية. أظهرت النتائج المتحصل طلئ عليها تفوق استجابة نباتات الحمص لاستخدام مزارع PPFM.C رشاََقارنة باستجابة محصول الفول البلدي لمزارع PPFM.F وذلك في أعداد و أوزان العقد البكتيرية والوزن الخضي لفري الخري الجاف للنباتات وأيضا المحتوي النيتروجيني. أجريت تجربة حقلية بموقع جنوب التحرير (أرض رملية طميية) بهدف دراسة تأثثر استخدام الرش رمنه

تحكيم: ا.د مجدي إسماعيل مصطفي ا.د فكري محمد غزال 